\title{
International History and the Study of Public Opinion: Towards Methodological Clarity
}

\begin{abstract}
International historians have long been fascinated by public opinion and its influence on policymaking, citing it frequently as one of the many factors that inform foreign policy choices. However, historians and international historians in particular - have yet to develop any substantial or rigorous methodological frameworks capable of revealing the actual influence of popular opinion at the highest levels of diplomatic policy. This article intends to redress this deficiency by outlining a methodological approach that elucidates the role of public opinion in the decision-making process. In so doing, it will also explore the tensions between different approaches to the study of international history, notably the apparent divergence between traditional 'diplomatic' history on the one hand and the more theoretically-diffuse 'international' history on the other. The conceptual framework forwarded here will suggest that the two approaches need not be in opposition, at least when seeking to explain the formative role of public opinion on foreign policymaking. Indeed, the careful application of inter-disciplinary theoretical frameworks not only enriches our understanding of international history in its totality, but also reveals much about the diplomatic fulcrum of our discipline.
\end{abstract}

Keywords: Public opinion, foreign policy, policymaking, representations, perceptions.

'Public opinion is a thing difficult to gauge with perfect accuracy', noted The Times in $1894 .{ }^{1}$ Certainly, 'public opinion' is an amorphous and slippery concept, almost impossible to grasp and notorious for its resistance to easy definition. Although difficult to pin down, public opinion exists nonetheless, and it is widely acknowledged that it exerts an influence especially in democracies - on the policymaking process. As a result, 'public opinion' as an object of academic study has a long history. ${ }^{2}$ Furthermore, the emergence of a 'scientific' approach to measuring public opinion has spawned an entire sub-discipline of the social sciences (as well as a self-contained industry of opinion pollsters) devoted to its analysis. However, historians remain reluctant to engage too deeply with public opinion. Although widely accepted as an important historical actor and frequently evoked as a causal factor in policymaking, such allusions are often fleeting, sometimes spurious, and usually unsatisfactory. As Elihu Katz remarked in 1995, 'we know too little about how public opinion

\footnotetext{
${ }^{1}$ Editorial, The Times, 12 Dec. 1894.

${ }^{2}$ For an overview of this, beginning with Thucydides' discussion of public opinion in History of the Peloponnesian War, see L. Benson, 'An Approach to the Scientific Study of Past Public Opinion', Public Opinion Quarterly, xxxi (1967-8), 532. See also R. M. Worcester, 'The Internationalization of Public Opinion Research', Public Opinion Quarterly, li (1987), S79.
} 
affects the process of governance - how it is anticipated, noticed, depicted, negotiated, incorporated and internalised.'3 Fifteen years on, we still know too little. This is particularly true of international history. As one scholar writing in the 1930 s noted, 'historians of international relations have rarely concerned themselves in detail with any phase of public opinion', deterred by its 'intangible character' and lack of 'satisfactory conclusions.'4 Little has changed in the eighty years since.

However, if international historians are serious about getting to grips with public opinion they must embrace more adventurous theoretical and methodological techniques, especially when assessing public opinion in a period pre-dating widespread opinion polling. But this need not require the abandonment of the traditional focus on the decision-makers; on the contrary, the application of theory can enhance our understanding of the diplomatic 'core', revealing how key decision-makers were influenced by public opinion. This article uses 'representations' as an analytical tool for identifying the dominant tendencies of public opinion that were actually perceived by the policymaking elites, and can thus be considered genuine historical actors. Specifically, two distinct categories of 'representation' are utilised. First, 'reactive' representations, referring to the more recognisable manifestations of public opinion that are frequently visible within the documentary record (e.g. newspapers, parliamentary debates, correspondence, etc.). Secondly, 'residual' representations, which refer to the more intangible manifestations of public opinion that cannot be ascertained simply by trawling archives or other traditional sources used by historians. Indeed, more imaginative and theoretical techniques are required to explain such 'residual' representations satisfactorily, and one such technique will be outlined in this paper. Before doing so, however, it is prudent to offer some preliminary remarks about the current status of the discipline of international history.

\section{The discipline of international history: theory and its discontents}

Several years ago, Zara Steiner described international history as 'a new field with an old pedigree.'5 This 'old pedigree' evokes the primacy of the Rankean tradition within the field, its emphasis on empirical data and its 'top down' focus on statesmen and diplomats when explaining the history of inter-state relations. Indeed, 'international history' was originally known as 'diplomatic history', which contributed to its (not entirely accurate) reputation for

3 E. Katz, 'Introduction', in T. L. Glasser and C. T. Salmon (eds), Public Opinion and the Communication of Consent (New York: The Guilford Press, 1995), xxi.

4 E. M. Carroll, French Public Opinion and Foreign Affairs, 1870-1914 (London: Frank Cass, 1931), 3-4.

5 Z. Steiner, 'On Writing International History: Chaps, Maps and Much More', International Affairs, lxxiii (1997), 531. 
pursuing a strict statist approach and emphasising the Primat der Aussenpolitik. But despite its reputation as an historical 'stick-in-the-mud', diplomatic history was never immune to changes affecting the wider discipline, absorbing influences from the Annales, Marxism, anthropology, economics, and so on. However, as Patrick Finney has remarked, it was only after the Second World War that diplomatic history was increasingly perceived as outmoded, and was subsequently reinvigorated by the injection of new and fresh approaches to historical problems. Diplomatic history had 'mutated' into 'international history.' More than simply a semantic adjustment, 'international history' encompassed a multiplicity of approaches, attending 'not only to diplomacy, but also to economics, strategy, the domestic sources of foreign policy, ideology and propaganda, and intelligence.' 6 Arguably, within these 'domestic sources of foreign policy', public opinion remains the most under-analysed and misunderstood.

Nevertheless, the scope of international history has broadened in recent decades, particularly in light of the 'cultural' and 'linguistic' turns. For Finney, this has enriched the discipline, encouraging practitioners to explore 'transnational cultural transfer, the activities of non-state actors and the discursive construction of foreign policy.'7 Similarly, Peter Jackson has observed that a plurality of approaches are now employed, examining how factors including race, gender, ethnicity and religion shape 'the social imagination of policymakers.'8 Of course, this plurality of approaches is not without its discontents, and many international historians believe that the impact of postmodernism should be resisted altogether or, at best, confined to the margins. David Reynolds has detected a 'diplomatic twitch' within the discipline, suggesting that whilst many practitioners acknowledge the influence of the 'cultural turn' they are disinclined to forsake the necessary focus on 'issues of war, peace and decision-making.'9 Similarly, T. G. Otte warns that abandoning the traditional 'diplomatic' approach would come 'at a price', and that 'the high politics of foreign policy decision-making and diplomacy as the instrument through which decisions were carried out must remain a principal concern of international history.' ${ }^{\prime}$

\footnotetext{
${ }^{6}$ P. Finney, 'Introduction: What is International History?' in Finney (ed.), Palgrave Advances in International History (Basingstoke: Palgrave Macmillan, 2005), 1

7 P. Finney, Remembering the Road to World War Two: International History, National Identity, Collective Memory (London: Routledge, 2010), 22.

${ }^{8}$ P. Jackson, 'Pierre Bourdieu, the “Cultural Turn” and the Practice of International History', Review of International Studies, xxxiv (2008), 155.
}

9 D. Reynolds, 'International History, the Cultural Turn and the Diplomatic Twitch', Cultural and Social History, iii (2006), 91. See also the subsequent debate between Reynolds, Finney and Antony Best in Cultural and Social History, iii (2006), 472-95.

${ }^{10}$ T. G. Otte, 'Diplomacy and Decision-Making', in Finney (ed.), Palgrave Advances in International History, 39. 
Despite such warnings, it is clear that alternative approaches can enlighten our understanding of the history of international relations (and, to be fair, neither Reynolds nor Otte would dispute this). After all, it is widely accepted that 'diplomatic history' is too narrow, failing to account for a multitude of causal factors in the foreign policymaking process. As Steiner has remarked, the discipline has 'long outgrown' the tendency to portray diplomatic history as simply 'what one clerk wrote to another.' ${ }^{11}$ Certainly, a greater plurality of approaches has compelled historians not only to engage with techniques from other disciplines, but also to think more carefully and thoroughly about their own use of theory. ${ }^{12}$ Nonetheless, this has proved to be a troublesome undertaking. As John Lewis Gaddis has observed, 'historians tend to respond to theory as small children do to spinach: we don't like it much, but we rarely explain why.' ${ }^{13}$ However, it would be erroneous to contend that all international historians are 'radical positivists', as few are instinctively hostile to theoretical developments. But, as Stephen Pelz has remarked, historians often apply theory too haphazardly, their lack of theoretical training meaning that 'each historian is her own methodologist.'14 Therefore, historians must be more careful and meticulous in their use of theory, but the extra effort demanded of theory-conscious historians will pay dividends. Indeed, the potential benefits of inter-disciplinarity have already been recognised. As Jeremy Black has observed, many historians 'have found it attractive or expedient to turn to the methods of other disciplines, notably sociology, anthropology, collective psychology, and political science.' 15

Nevertheless, many remain wary of inter-disciplinary techniques, dismayed that theorists and philosophers, untrained in the rigours of traditional historical practice, are now telling historians how to do their job. For international historians especially there has been a sense that their subject has been co-opted by theorists who 'do not do this history as historians can and should do it.'16 Although many practitioners will acknowledge - and even

\footnotetext{
${ }^{11}$ Steiner, 'On Writing International History', 531.

${ }^{12}$ See, for example, Robert Young's thoughtful reflection on how his own background, beliefs and attitudes have shaped his work on French history: R. J. Young, 'Formation and Foreign Policy: Biography and Ego-histoire', French History, xxiv (2010), 144-63.

13 J. L. Gaddis, 'In Defense of Particular Generalization: Rewriting Cold War History, Rethinking International Relations Theory', in C. Elman and M. F. Elman (eds), Bridges and Boundaries: Historians, Political Scientists, and the Study of International Relations (Cambridge, MA: The MIT Press, 2001), 301.

14 Ibid., 87.

15 J. Black, Debating Foreign Policy in Eighteenth-Century Britain, (Farnham: Ashgate, 2011), xii.

${ }^{16}$ This concern was remarked upon in the editors' 'Introduction' in Elman and Elman (eds), Bridges and

Boundaries, 4. Similarly, the 'diplomatic twitch' invoked by Reynolds can be seen as a backlash against 'culturalist' international history. Reynolds, 'International History', 75-91. For an overview of 'culturalist' approaches, see A. J. Rotter, 'Culture', in Finney (ed.), Palgrave Advances in International History, 267-99.
} 
embrace - diverse approaches and methodologies, there is an almost instinctive resistance to any substantial deviation from the traditional focus on decision-makers and their social environment. This is no great surprise. After all, even Patrick Finney, a staunch advocate of cultural approaches, accepts that international history will always place a heavy emphasis 'on grasping the causes of things', necessitating a focus on decision-makers and the machinery of decision-making. ${ }^{17}$ Although international history has rightly moved beyond a uniquely state-centric approach, it is difficult to envisage a time when the study of international relations will not be dominated by issues of war and peace. It can, therefore, be argued that the seismic shifts affecting the theory and practice of the wider discipline have had only a marginal impact on international history. But such an argument only holds water at a superficial level, as recent academic developments and trends have not been without effect. Above all, international historians are now more theoretically self-conscious, more aware of their own subjectivity, and more amenable to inter-disciplinary approaches. Indeed, this should come as no surprise; international historians have never been as impervious to external influences as its critics would suggest.

Despite this, international historians can certainly profit from embracing and developing innovative theoretical approaches capable of assisting them in 'reconstructing the decision-maker's knowledge, experience and expectations.' ${ }^{18}$ To be sure, historians can embrace inter-disciplinary approaches without sacrificing the centrality of the decisionmaking process in their analyses. As Markus Mösslang and Torsten Riotte have recently suggested, the cultural turn 'adjusts the focus' away from conventional diplomatic history but it does not exclude it. ${ }^{19}$ One area in which the two approaches can be complementary is in assessing the causal role of public opinion. On the one hand, public opinion is the object of sustained and thorough academic analysis, particularly within the social sciences. However, within the field of international history, the issue of public opinion remains relatively underdeveloped, particularly the interplay between public opinion and foreign policymaking. ${ }^{20}$ This article suggests that engagement with more theoretical approaches to

Peter Jackson, who is generally receptive to recent trends and developments, has also identified drawbacks to 'culturalist' approaches, suggesting that they need to be applied more thoughtfully and carefully to the study of international history. See Jackson, 'Pierre Bourdieu', 162.

${ }_{17}$ P. Finney, 'The Diplomatic Temptation', Cultural and Social History, iii (2006), 475.

18 Pelz, 'Toward a New Diplomatic History', 99.

${ }_{19}$ M. Mösslang and T. Riotte, 'Introduction: The Diplomats' World', in Mösslang and Riotte (eds), The Diplomats' World, 10.

${ }^{20}$ Despite being relatively scarce, analyses that focus on public opinion (particularly journal articles and chapters) are nonetheless too numerous to list in full, so a 'sample' of relevant monographs will have to suffice: Y. Lacaze, L'opinion publique française et la crise de Munich (Bern: Peter Lang, 1991), J.-L. Crémieux-Brilhac, Les Français de l'an 4O, 2 vols. (Paris: Gallimard, 1990), J.-J. Becker, 1914: comment les Français sont entrés dans la guerre: 
the study of public opinion can shed some much-needed light on the public opinion/foreign policy nexus and thus enhance our overall understanding of the decision-making process in particular and diplomatic history in general. Indeed, the remainder of this article will demonstrate both the possibilities for, and the practical benefits of, theoretical and methodological pluralism.

\section{Theorising the public opinion-policymaking interface: The lay of the land}

The reluctance of historians to tackle public opinion research is not shared by political scientists, particularly in the United States. The resultant literature is massive, and continues to grow at a rapid rate. However, the problems posed by a subject as nebulous as public opinion are apparent from the lack of an accepted definition. At a conference of American political scientists in 1924 a motion was passed asserting that because it is impossible to provide a standardised definition of public opinion ... it is preferable, if possible, to avoid using the term. ${ }^{21}$ For historians interested in the influence of public opinion on the policymaking process, the lack of a workable definition is problematic. Simply put, to assess the influence of something, we need to know what that 'something' actually is. Lee Benson draws a parallel with Mrs Glasse's famous opening step in making a hare ragoût - 'first, catch your hare'. Benson's recipe for 'assessing the causal role of public opinion' necessarily begins: 'First, catch your public opinion.'22 Of course, this is easier said than done, especially as the majority of political scientists rely heavily on opinion poll data to 'catch' it. For

contribution à l'étude de l'opinion publique printemps-été 1914 (Paris: Presses de la FNSP, 1977), E. M. Carroll, French Public Opinion and Foreign Affairs, 1870-1914, Waley, British Public Opinion and the Abyssinian War, 1935-6 (London: Maurice Temple Smith, 1975), L. M. Case, French Opinion on War and Diplomacy during the Second Empire (Philadelphia: University of Pennsylvania Press, 1954), K. A. Sandiford, Great Britain and the Schleswig-Holstein Question, 1848-64: A Study in Diplomacy, Politics and Public Opinion (Toronto: University of Toronto Press, 1975), P. Miquel, La paix de Versailles et l'opinion publique française (Paris: Flammarion, 1972), R. B. McCallum, Public Opinion and the Last Peace (Oxford: Oxford University Press, 1944), D. F. Schmitz, The Tet Offensive: Politics, War, and Public Opinion (Lanham, MD: Rowman and Littlefield, 2005), J. M. Hogan, Woodrow Wilson's Western Tour: Rhetoric, Public Opinion and the League of Nations (College Station: Texas A\&M University Press, 2006), D. Hucker, Public Opinion and the End of Appeasement in Britain and France (Farnham: Ashgate, 2011), S. Casey, Cautious Crusade: Franklin D. Roosevelt, American Public Opinion, and the War against Nazi Germany (Oxford: Oxford University Press, 2003), and by the same author, Selling the Korean War: Propaganda, Politics, and Public Opinion, 1950-1953 (Oxford: Oxford University Press, 2008).

${ }^{21}$ Cited in P. Beaud, 'Common Knowledge on Historical Vicissitudes of the Notion of Public Opinion', Réseaux, i (1993), 119. See also the editors' 'Introduction' in W. Donsbach and M. W. Traugott (eds), The SAGE Handbook of Public Opinion Research (London: SAGE Publications, 2005), 1-5.

${ }^{22}$ Benson, 'An Approach to the Scientific Study of Past Public Opinion', 551. 
historians without recourse to such data, there is an obvious problem. As one scholar has remarked, 'the historian of opinion who builds on opinion polls may possibly be building on sand, but his foundations are certainly on a different sort of material from those of historians of earlier periods.' ${ }^{23}$

Although a convincing and accurate definition of public opinion remains elusive, research into its influence on the policymaking process has been more fruitful. Early analyses, based on the pioneering work of Walter Lippmann and Gabriel Almond, suggested that public opinion had an injurious impact on the foreign policymaking process. Lippmann viewed public opinion as a detrimental constraint on policymakers, too often ill-informed or simply wrong, compelling 'wiser' governments to take imprudent decisions.'24 Almond offered a similarly negative appraisal, claiming that American public opinion was largely 'indifferent' to matters of foreign affairs, characterised by media-fuelled 'moods' that serve only to distort the government's foreign and strategic policy choices. ${ }^{25}$ Bernard C. Cohen, however, in an important and influential book examining the role of public opinion on foreign policy decision-making, offered an alternative interpretation. Whilst agreeing that illinformed mass opinion may contribute to regrettable policy decisions, he argued that, in reality, decision-makers largely ignore it. Indeed, the most frequently-cited sentence from Cohen's book is where he quotes an American State Department official: 'To hell with public opinion ... We should lead and not follow.'26 Moreover, in an earlier piece, Cohen suggested that tracing the influence of public opinion on foreign policy, especially in an era pre-dating opinion polls, was futile. For Cohen, little confidence could be placed in historical assessments of 'an earlier period that are based, unavoidably, on a selective reading of the press or on the accounts of one or at most a few observers or participants. ${ }^{27}$

Hence a new consensus held that public opinion, at least with regard to foreign policymaking, was of negligible importance. However, the terrain shifted again during and after the Vietnam War. Studies emerged demonstrating that American public opinion, rather than being fickle and subject to changing 'moods', was relatively stable, and had been throughout the Cold War era. Moreover, it wielded a genuine influence on foreign policy

\footnotetext{
23 Waley, British Public Opinion and the Abyssinian War, 11.

24 W. Lippmann, Essays in the Public Philosophy (Boston: Little, Brown and Co., 1955), 20 \& 24.

25 G. A. Almond, The American People and Foreign Policy, (New York: Praeger, 1960), 53, and Almond, 'Public Opinion and National Security', Public Opinion Quarterly, xx (1956), 376.

${ }^{26}$ B. C. Cohen, The Public's Impact on Foreign Policy (Boston, Little, Brown and Co., 1973), 62.

27 B. C. Cohen, 'The Relationship between Public Opinion and Foreign Policy Maker', in M. Small (ed.) Public Opinion and Historians: Interdisciplinary Perspectives (Detroit: Wayne State University Press, 1970), 69-70.
} 
decisions. ${ }^{28}$ Such revisionism had a profound impact on our appreciation of opinion. Ole Holsti remarked that 'the earlier consensus about public impotence' had been gravely undermined, while Powlick and Katz detected a new consensus: 'Few now question that American public opinion has an effect on foreign policymakers.'29 For the historian of public opinion, this claim raises several questions. First, if we accept that American public opinion influences American foreign policymakers, must public opinion in other countries have an analogous effect on their government's foreign policy decisions? Second, is this link only true of the period scrutinised by the political science literature, namely the era of widespread opinion polling and mass communication (particularly television)? Can historians make similar claims or inferences about earlier periods, when scientifically-rigorous survey data is not available?

With regard to the first question, it has long been accepted by historians that public opinion does influence the decision-making elite. Robert Worcester notes Abraham Lincoln's assertion that 'public opinion is everything', while E. Malcolm Carroll argued persuasively that 'there is abundant evidence that public opinion was a fairly constant factor in the conduct of [French] foreign affairs' from the Franco-Prussian War to the Great War: 'public opinion was almost always a factor in the calculations of diplomats and of governments.'30 An earlier historian, discussing public opinion during Disraeli's premiership, contended that 'no government that ever existed, not even the most despotic, has ever been able to shake itself quite loose from all restraint imposed by Public Opinion.' ${ }^{31}$ More recently, Sylvia Hilton remarks that both Spanish and American accounts of the 1898 Spanish-American War routinely 'stress the importance of public opinion and the press, and their connection with the political decisions leading to the war.' ${ }^{2}$

\footnotetext{
${ }^{28}$ See, for example, P. J. Powlick and A. Z. Katz, 'Defining the American Public Opinion/Foreign Policy Nexus', Mershon International Studies Review, xlii (1998), 30, J. Hurwitz and M. Peffley, 'How are Foreign Policy Attitudes Structured: A Hierarchical Model', American Political Science Review, lxxxi (1987), 1099-1120, R. Y. Shapiro and B. I. Page, 'Foreign Policy and the Rational Public', Journal of Conflict Resolution, xxxii (1988), 21147, and T. W. Graham, 'The Pattern and Importance of Public Knowledge in the Nuclear Age', Journal of Conflict Resolution, xxxii (1988), 319-34.

29 O. R. Holsti, 'Public Opinion and Foreign Policy: Challenges to the Almond-Lippmann Consensus', International Studies Quarterly, xxxvi (1992), 451-2; Powlick and Katz, 'Defining the American Public Opinion/Foreign Policy Nexus', 30.

$3^{\circ}$ Worcester, 'Internationalization of Public Opinion Research', S79; Carroll, French Public Opinion and Foreign Affairs, 3 .

${ }^{31}$ G. C. Thompson, Public Opinion and Lord Beaconsfield, 1875-188o, vol. 1 (London: Macmillan, 1886), 3.

${ }^{2}$ S. Hilton, 'The Spanish-American War of 1898: Queries into the Relationship between the Press, Public

Opinion and Politics', Revista Española de Estudios Norteamericanos, vii (1994), 71.
} 
Foreign policymakers themselves have also alluded to the importance of public opinion. As early as 1826, the British Prime Minister George Canning referred to 'the fatal artillery of popular excitation'. In 1899, Lord Salisbury lamented how the British government was now absolutely dependent on the 'aura popularis'. Furthermore, in 1908, a German official at the Auswärtiges Amt noted how 'the public opinion of the nations has acquired a degree of influence on political decisions previously unimaginable.'33 In the early Cold War, US secretary of state John Foster Dulles surmised succinctly that, 'in the long run it isn't only bombs that win wars, but having public opinion on your side'. ${ }^{34}$ Furthermore, since the latenineteenth and particularly into the twentieth century, statesmen became conscious not only of domestic public opinion but of opinion on a global scale. Commenting on the results of the first Hague Peace Conference in 1899, Sir William Everett of the British War Office remarked that 'the increased power of the sentiments of humanity' provided a moral compulsion to govern the future conduct of wars above and beyond the statutes of binding conventions. 35 More famously, following the horrors of the Great War, Woodrow Wilson asserted confidently that the ultimate sanction underpinning his projected League of Nations lay in 'the moral force of the public opinion of the world. ${ }^{3} 6$

But demonstrating a tangible link between public opinion and foreign policy choices remains problematic, especially without opinion poll data to work with. Ultimately, alternative means for gauging public opinion do not provide the reliable and empirical 'facts' furnished by pollsters. But alternative sources are not without value. For example, Lynn M. Case used an array of documentation produced by the authorities of the French Second Empire to paint a compelling portrait of public opinion as it was understood by the contemporary political elites. ${ }^{37}$ Similarly, David Bankier's study of public opinion in Nazi Germany uses the Lageberichte (situation reports) and the Stimmungsberichte (mood

\footnotetext{
33 Canning cited in Harold Nicolson, Diplomacy, (London: Thornton Butterworth Ltd., 1939), 168; Salisbury cited in Keith Wilson, 'Introduction: Governments, Historians and "Historical Engineering”, in Keith Wilson (ed.), Forging the Collective Memory: Government and International Historians through Two World Wars (Oxford: Berghahn Books, 1996), p. 18; the Auswärtiges Amst official cited in D. Geppert, 'The Public Challenge to Diplomacy: German and British Ways of Dealing with the Press, 1890-1914', in Mösslang and Riotte (eds), The Diplomats' World, 134 .

34 Dulles memorandum, 16 May 1954, Foreign Relations of the United States, 1952-1954, 2, 1448.

35 Note by Sir W. Everett on the Convention concerning the Laws and Customs of War on Land, 7 Oct. 1899, The National Archives [TNA], Kew, London, FO 881/7473, no. 289, enclosure no. 3.

${ }^{36}$ Wilson to the Plenary Session of the Paris Peace Conference, 14 Feb. 1919, cited in Lloyd E. Ambrosius, Woodrow Wilson and the American Diplomatic Tradition: The Treaty Fight in Perspective, (Cambridge: Cambridge University Press, 1987), 78.

37 Case, French Opinion on War and Diplomacy.
} 
reports) put together by Germany's security apparatus as means of gauging wider opinion. ${ }^{38}$ Indeed, the careful monitoring of the population by authoritarian regimes can provide the historian with a meticulous record of the public spirit that is simply not afforded the historian of a democratic state. For example, an historian of Vichy France is assisted greatly by the abundant monthly reports produced by the departmental prefects, including sections assessing the 'état d'esprit' of the local populace. 39

But such sources are not always available, especially when it comes to public attitudes towards foreign policy issues. As a result, international historians are often compelled to cast their net more widely. For example, Keith Sandiford, in his exploration of British public opinion regarding the Schleswig-Holstein question, noted how the inability to gauge "the feelings of the silent majority' leaves historians of the mid-Victorian era little option but to focus upon the elites, whose diaries, personal papers and correspondence provides some evidence of comment and opinion..$^{\circ}$ But focussing on social and political elites is not necessarily a bad thing. For international historians in particular, such an approach is the most accurate way of re-creating how public opinion was perceived in decision-making circles. Indeed, the historian's task is to recreate, as accurately as possible, the social environment in which contemporary policymakers arrived at their understanding of popular opinion. In short, it is necessary to identify which sources were capable of informing the perceptions of public opinion held in the corridors of power. For example, Yvon Lacaze's massive study of French public opinion during the 1938 Sudeten crisis focuses on the government, parliament, political parties, newspapers, and specific social groups (such as freemasons, business leaders and farmers) in an effort to paint an overall portrait of French opinion. ${ }^{41}$ However, despite using a plethora of sources, Lacaze relied most heavily on the popular press. In so doing he reflected the proclivity of historians to use newspapers as an indicator of public sentiment. As Lothar Reinermann notes, in the absence of opinion polls it is inevitable that historians will turn to the press. But the focus on newspapers is not only a matter of expediency; as Laura Beers remarks, newspapers had, by the interwar period,

\footnotetext{
${ }^{8}$ D. Bankier, The Germans and the Final Solution: Public Opinion under Nazism (Oxford: Blackwell, 1992$), 4$. See also I. Kershaw, Popular Opinion and Political Dissent in the Third Reich: Bavaria, 1933-1945, (Oxford: Clarendon Press, 1983), 5.

39 These can be consulted on-line: http://www.ihtp.cnrs.fr/prefets/ (accessed 9 December 2011).

40 Sandiford, Great Britain and the Schleswig-Holstein Question, 17.

${ }^{41}$ Lacaze, L'opinion publique française, 47.
} 
'become most Britons' primary source of national and international news', thus playing an important role in 'opinion formation.' 42

Of course, historians do recognise the limitations of such an approach, but, without opinion poll or other survey data to work with, they see little alternative. As Brett Holman concludes, using the press to gauge opinion might be an imperfect approach but it is the 'best we have.'43 Furthermore, it is worth noting that many politicians and diplomats themselves believed that the press was an accurate and reliable conduit of the popular mood. Indeed, France's ambassador to London during the 1930s, Charles Corbin, was only prepared to accept the findings of the fledgling British Institute of Public Opinion when they corresponded with the 'permanent barometer of opinion' that was the press. ${ }^{44}$ To be sure, there is a correlation between the emergence of a mass circulation press and a growing political sensitivity to the phenomena of public opinion. For the British diplomat, Sir Harold Nicolson, the emergence of a 'new' diplomacy in the early twentieth-century was attributable, at least in part, to both 'an increasing appreciation of the importance of public opinion', and a 'rapid increase in communications.' 45 Nevertheless, the influence that subsequent perceptions of opinion had on the policy-making process is debatable. Paul Kennedy acknowledges that it was a factor in decision-making, but warns against assuming that 'statesmen and permanent officials became the helpless puppets of the press.' 46 But simply by acknowledging the press as a factor, Kennedy, like the vast majority of international historians, would concur with Dominik Geppert's assertion that newspapers should not be seen 'as an external factor in political actions, but as a constitutive element within the political culture that produces and conditions political decisions in the first place.'47

\footnotetext{
${ }^{42}$ L. Reinermann, 'Fleet Street and the Kaiser: British Public Opinion and Wilhelm II', German History, xxvi (2008), 470; L. Beers, “Is This Man an Anarchist?” Industrial Action and the Battle for Public Opinion in Interwar Britain', The Journal of Modern History, lxxxii (2010), 35.

43 B. Holman, 'The Air Panic of 1935: British Press Opinion between Disarmament and Rearmament', Journal of Contemporary History, xlvi (2011), 289-91.

44 Corbin to Georges Bonnet (French foreign minister), 29 Nov. 1938 [Archives du Ministère des Affaires Etrangères, Paris], Série Z, no. 281.

45 Nicolson, Diplomacy, 70. For examples of this growing awareness of, and sensitivity to, the press in nineteenth century Britain, see D. Halvorson, 'Prestige, Prudence and Public Opinion in the 1882 British Occupation of Egypt', Australian Journal of Politics and History, lvi (2010), 430, and D. Brown, 'Diplomacy and the Fourth Estate: The Role of the Press in British Foreign Policy in the Age of Palmerston', in J. Fisher and A. Best (eds), On the Fringes of Diplomacy: Influences on British Foreign Policy, 180o-1945, (Farnham: Ashgate, 2011), 37, 51.. ${ }^{46}$ P. Kennedy, The Realities Behind Diplomacy: Background Influences on British External Policy, 1865-1980 (London: Fontana, 1981), 56. 47 D. Geppert, Pressekriege: Öffentlichkeit und Diplomatie in den deutsch-britischen Beziehungen (1896-1912) (Munich, 2007), 5.
} 
Although decision-makers might have viewed newspapers as an accurate 'barometer' of opinion, historians must be wary of making such assumptions. Similarly, they must avoid simply parroting what they uncover in the archival record, interpreting what policymakers say about public opinion as a genuine affirmation of the public mood. As Melvin Small contends, 'for generations historians interested in public opinion have concentrated on elite opinion and confused the two.'48 But if our interest is in the influence of public opinion on policymakers, such criticisms are less potent. After all, erroneous perceptions of a public opinion that did not exist were more influential than any genuine opinion that was never perceived. Therefore, international historians should focus on identifying how perceptions of public opinion (whether accurate or otherwise) influenced foreign policy choices, which is by no means the same as attempting to recreate public opinion 'as it was'. This is not to preclude any alternative approach; indeed, analyses of wider public opinion (or public opinion on a transnational level) are equally valuable, even if such opinions had little or no bearing on policy choices. But when assessing the actual influence of public opinion on the foreign policymaking process, isolating only those opinions perceived within the corridors of power is essential.

However, this is no easy endeavour. One particularly fruitful approach is that employed by Steven Casey in his analysis of American public opinion during the Second World War. Casey seeks to 'trace' references to public opinion within the documentary record, and then determine the level of 'congruence' between policymakers' reading of opinion and their subsequent decisions: 'if the president's assumptions, decisions, and timing were all in diametric opposition to his reading of the popular mood, then public opinion can be written off as an irrelevant factor. But if his actions were in some way congruent, then we can conclude that popular opinion probably played some role.'49 As useful as this process of 'tracing' is, there is scope for alternative approaches. After all, Casey (like Roosevelt) was able to draw on opinion poll data in order to 'catch' American public opinion. Not all international historians can fall back on opinion surveys, so instead need to rely on other sources. Once again, this raises the vexing question of their reliability. After all, while sources such as newspaper commentary, police reports, diaries and correspondence are certainly useful, they nonetheless lack the empirical accuracy of scientifically-rigorous opinion polls.

However, this drawback compels us to ponder one of the fundamental debates concerning historical method and practice. That is, can history ever be genuinely scientific,

\footnotetext{
${ }^{48}$ M. Small, 'Historians Look at Public Opinion', in Small (ed.), Public Opinion and Historians: Interdisciplinary Perspectives (Detroit: Wayne State University Press, 1970), 16.

49 Casey, Cautious Crusade, xxiv-xxv.
} 
providing objective and indisputable facts? Obviously, recent academic trends have gone a long way towards rendering such a question redundant. It is now widely accepted that the natural sciences are just as vulnerable to subjective interpretation as history or the social sciences..$^{\circ}$ In sum, if one accepts that scientific 'facts' can never be entirely independent of theory, perhaps it is necessary, with regard to the historical study of public opinion, to resist the temptation to fetishise opinion poll data. Despite their 'scientific' nature, they too are subject to interpretation, inevitably tainted by an individual's subjective ideological beliefs. Indeed, opinion polls are not without their critics. Pierre Bourdieu famously declared that 'public opinion does not exist', claiming that opinion polls, by their very nature, act to shape rather than reflect opinion..$^{51}$ Similarly, social theorists including Herbert Blumer, Jürgen Habermas and Michel Foucault, have argued that polling distorts rather than enhances our understanding of opinion. ${ }^{2}$ Such critiques have certainly influenced the field of public opinion research. In 1995, Charles Salmon and Theodore Glasser opined that 'polls not only miss the mark but shift the target [providing] at best a naive and narrow view of democracy; they posit a conception of participation that confuses a plebiscitary system with a democratic one.'53 More recently, in 2007, in a keynote address to the conference of the World Association for Public Opinion Research, Kurt Lang contended that opinion polling alone provides only a partial representation of public sentiment that potentially overlooks more informal, but no less important, indicators of the public mood. 54

Perhaps, then, historians working on periods before the advent of opinion polling, using a diverse array of public opinion indicators, are on to something after all. Maybe the positivist fixation on the 'scientific' data furnished by opinion surveys has blinded us to the value of other sources. After all, historians have always utilised alternative methods of gauging the popular mood. As Pierre Laborie has claimed, 'even in the absence of opinion polls, a history of opinion remains possible.'55 Nevertheless, Susan Herbst is correct in noting that, 'when most of us consider the meaning of public opinion, we can't help but think about

\footnotetext{
$5^{\circ}$ M. Trachtenberg, The Craft of International History: A Guide to Method (Princeton: Princeton University Press, 2006), 27.

${ }^{51}$ P. Bourdieu, 'L’opinion publique n'existe pas', Les temps modernes, cccxviii (1973), 1292-1309.

$5^{2}$ H. Blumer, 'Public Opinion and Public Opinion Polling', American Sociological Review, xiii (1948), 542-9; J. R. Beniger, 'The Impact of Polling on Public Opinion: Reconciling Foucault, Habermas, and Bourdieu', International Journal of Public Opinion Research, iv (1992), 207. For a detailed exposition of opinion polling, see L. Blondiaux, 'Ce que les sondages font à l'opinion publique', Politix, x (1997), 117-36.

53 C. T. Salmon and T. L. Glasser, 'The Politics of Polling and the Limits of Consent', in Salmon and Glasser (eds), Public Opinion and the Communication of Consent, 449

54K. Lang, 'What Polls Can and Cannot Tell Us about Public Opinion: Keynote Speech at the $60^{\text {th }}$ Annual Conference of WAPOR', International Journal of Public Opinion Research, xx (2008), 17.
}

55 P. Laborie, 'De l'opinion publique à l’imaginaire social', Vingtième Siècle, Revue d'histoire, xviii (1988), 104. 
polls or surveys.' Despite this, Herbst encourages 'historians of public opinion [to] try to piece together past connotations of "public opinion" by evaluating memoirs, newspapers, civic texts, and other cultural artefacts'. Although the available archival sources 'may be hard to find', and even then prove 'incomplete or of dubious veracity', Herbst is adamant that such an endeavour is not only possible but essential if historians are to reveal the genuine influence of public opinion. ${ }^{56}$

The sources available are obviously context-specific, but focusing on expressions of public opinion that permeated the corridors of power will highlight the most pertinent. The documentary record can reveal which expressions of opinion reverberated most emphatically in policymaking circles, and thus entered the consciousness of the decision-makers themselves. As Floyd Allport asserted in the very first edition of the journal Public Opinion Quarterly, 'There can be no such thing as opinion without stating the content of the opinion in language form.'57 Opinions that were not stated or expressed in such a way, or were unable to reach the decision-makers, can be disregarded. To be sure, such a narrow conception of public opinion is problematic, but the reasons for taking such an approach can be explained by referring to Habermas' seminal theories regarding the 'public sphere', theories that have informed numerous historical analyses of popular opinion..$^{8}$ For Habermas, it was only with the emergence of an educated bourgeois class in eighteenth-century Europe that an 'articulated' public opinion came into being. ${ }^{59}$ Although Habermas' 'public sphere' has been criticised for ignoring or overlooking other expressions of popular sentiment ${ }^{60}-$ particularly the opinions of women - it nonetheless identifies the specific expressions of public opinion

\footnotetext{
${ }^{6} \mathrm{~S}$. Herbst, 'On the Disappearance of Groups: $19^{\text {th }}$ - and Early $20^{\text {th }}-$ Century Conceptions of Public Opinion', in Glasser and Salmon (eds), Public Opinion and the Communication of Consent, 90-91.

57 F. H. Allport, 'Toward a Science of Public Opinion', Public Opinion Quarterly, i (1937), 14.

$5^{8}$ For example, Mona Ozouf and Keith Baker have used Habermas when writing extensively and persuasively about the role of 'opinion publique' in revolutionary-era France See Ozouf, "Public Opinion” at the End of the Old Regime', The Journal of Modern History, lx, supplement (1988), S1-S21, and 'Quelques remarques sur la notion d'opinion publique au XVIIIe siècle', Réseaux, v (1987), 79-103; Baker Inventing the French Revolution. Essays on French Political Culture in the Eighteenth Century (Cambridge: Cambridge University Press, 1990), 'Politics and Public Opinion under the Old Regime: Some Reflections', in J. Censer and J. Popkin (eds.), Press and Politics in Pre-Revolutionary France (Berkeley: University of California Press, 1987), 205-246, and 'Politique et opinion publique sous l'ancien regime', Annales, xlii (1987), 41-71. For more on the importance of Habermas, see J. Cowans, 'Habermas and French History: The Public Sphere and the Problem of Political Legitimacy', French History, xiii (1999), 134-60.

59 See J. Habermas, The Structural Transformation of the Public Sphere: An Inquiry into a Category of Bourgeois Society, trans. Thomas Burger (Cambridge, MA: The MIT Press, 1989).

6o J. B. Thompson, The Media and Modernity: A Social Theory of the Media (Cambridge: Polity Press, 1995$), 71$. For more on the various critiques of Habermas, see L. Goode, Jürgen Habermas: Democracy and the Public Sphere (London: Pluto Press, 2005), 29-55 \& 89-106.
} 
that wielded a genuine influence. Opinions that were expressed less forcibly, less publicly, or even not expressed in language form at all, whilst still a part of public opinion per se (and thus worthy of study in their own right), are negligible when considering the influence of opinion on policymakers.

The Habermasian 'public sphere' provides a useful analytical tool for the historian interested in opinion. Furthermore, it demanded a re-evaluation of what exactly is meant by the term 'public opinion'. As Craig Calhoun has remarked, Habermas moves beyond the more general concept of the 'volonté général' conveyed by Rousseau, and beyond the influential but cumbersome conceptions of opinion articulated by thinkers as diverse as Hobbes, Locke, Hegel, Marx and Tocqueville. In its place, he posited a more 'positive' conception of public opinion, referring to 'the views held by those who join in rationalcritical debate on an issue.' ${ }^{61}$ For Habermas, this conception went hand-in-hand with the development of democracy; as education and literacy increased, and as newspapers proliferated, so the 'public sphere' widened to include ever more, previously marginalised sections of society. However, the expansion of the 'public sphere', while beneficial for democracy, posed a dilemma for policymakers. With an increasing number of voices vying to be heard, it was more difficult for the politicians to ascertain what public opinion on any given issue was.

Just as this was a problem for contemporary decision-makers, so too is it a problem for historians looking back, who are tasked with identifying correctly which expressions of opinion permeated the consciousness of the politicians and thus genuinely influenced the policymaking process. This is no easy endeavour, even if the existence of an influential minority - or what Gladstone referred to as a 'the upper ten thousand' - has long been accepted. ${ }^{62}$ Nevertheless, a methodological approach based on 'representations' and 'perceptions' can elucidate more effectively how politicians and diplomats understood and responded to public opinion. Borrowing heavily from the work of Pierre Laborie, in conjunction with research from the discipline of social psychology, it will be argued that the political impact of public opinion can be comprehended only inasmuch as public opinion was perceived by the decision-making elites, and that these perceptions can best be understood via a notion of representations. ${ }^{63}$ In short, the intangible phenomena of public opinion was only understood (and thus perceived) within the corridors of power by virtue of how it was represented to them. A conceptual framework of 'representations' can be used to identify the

\footnotetext{
${ }^{61}$ C. Calhoun, 'Introduction', in Calhoun (ed.), Habermas and the Public Sphere (Cambridge, MA: The MIT Press, 1992), 17.

62 Cited in Kennedy, Realities Behind Diplomacy, 38.

63 Laborie, 'De l'opinion publique à l’imaginaire social', 117.
} 
perceptions of public opinion that influenced the decision-making elites and thus contributed towards foreign policy choices.

\section{An alternative methodology: 'Representations' and elite 'perceptions' of public opinion}

Pierre Laborie has written extensively on Vichy-era France, using 'representations' as a tool for recreating contemporary French public opinion. Laborie contends that a concept of representations enables the historian to locate, amongst the plethora of divergent expressions of public opinion, how specific 'dominant' tendencies emerge. These 'dominant' tendencies, he suggests, provide 'a common notion of opinion', akin to a shared perception of what opinion actually is. Given that public opinion is not homogenous, such 'common notions' are crucial in explaining how it was reduced to a manageable number of assumptions, beliefs and perceptions. Moreover, when attempting to explain how public opinion influenced the policymaking process, identifying shared perceptions enables the historian to 'define the historical status of the phenomena of opinion, and its place in the explanatory process.' 64

Representations are thus used as a methodological tool for locating what historians have always assumed to exist: dominant tendencies of public opinion. Indeed, it has long been accepted that it is misleading to speak of 'public opinion' in the singular. As René Rémond noted, we do so only through 'convention', whereas in reality we are confronted with a 'multiplicity of opinions.' 65 Identifying 'dominant tendencies' within this multiplicity of opinions is pivotal, and this is, in essence, what Habermas's 'public sphere' accomplishes; it was only here that opinions were capable of being heard and thus wielding influence. Indeed, in her analysis of Scottish public opinion at the time of the Anglo-Scottish Union, Karin Bowie draws on both Habermas and a notion of 'representations' when identifying two levels of public opinion: first, the 'actual opinions of individuals', and second, the 'representations of opinion created to influence political authorities.'66 Evidently, the latter category is crucial when seeking to determine opinion's actual influence on policymakers. Hence it is unsurprising that historians gravitate to expressions of opinion that are visible and, more importantly, those that can be discovered in the documentary record. As E. Malcolm Carroll observed in 1931, in its common use, [public opinion] refers to the

\footnotetext{
64 P. Laborie, Les Français des années troubles: De la guerre d'Espagne à la Libération (Paris: Desclée de Brouwer, 2001), 38.

65 R. Rémond, preface to J.-J. Becker's 1914, 1.

${ }^{66}$ K. Bowie, Scottish Public Opinion and the Anglo-Scottish Union, 1699-1707 (Woodbridge: The Royal Historical Society, 2007), 1.
} 
composite reactions of the general public, but as a rule, the only tangible evidence of these tendencies is to be found in the opinions of the more influential leaders.' ${ }^{2} 7$

At first glance, therefore, a notion of 'representations' would appear to offer little more than a means of ascertaining the dominant tendencies of opinion, something that historians have always tried to do. However, this technique provides a more nuanced appreciation of how these dominant tendencies of opinion emerge, which is not always readily apparent from the documentary record alone. As Laborie remarks, the absence of observable expressions of opinion does mean there is no opinion at all. Furthermore, he suggests that 'the silences, the un-said, the inertia and the pauses' are not insignificant; on the contrary, they provide the historian with 'many revelations, charged with meaning.' 68 Therefore, the tool of representations not only advances our understanding of how dominant tendencies of opinion emerge but also reveals how other tendencies are marginalised or even concealed altogether. In essence, it is not necessarily the 'opinion' itself that is (or becomes) dominant; instead, the dominance of any given 'opinion' arises from the very process of its representation, benefitting by being represented volubly, repeatedly, or merely in the right places at the right times. The extent to which public opinion wielded a genuine influence on the policymaking process can only be understood if one locates, within the plethora of 'public opinions', which specific tendencies permeated the consciousness of the political elites. The only 'public opinion' that influenced policy was that which was recognised and understood in the corridors of power, as perceived via a process of social representations.

At this juncture, it is prudent to elaborate further on the understanding of the term 'representation' as used in this essay. Borrowing heavily from the work of French historians and French social psychologists, it is predicated upon the représentations sociales outlined by Serge Moscovici, who himself was influenced heavily by Durkheim's conception of 'collective representations' ${ }^{69}$ The process of representation, therefore, refers to both the act of public opinion being 'represented', and the manner in which individuals and collective groups (e.g. policymakers) internalise and make sense of these representations. It is this latter phenomenon, for which there is little empirical or 'hard' proof, that sits so uncomfortably with theory-averse historians, and which benefits most from engaging with

\footnotetext{
67 Carroll, French Public Opinion and Foreign Affairs, 4-5.

68 Laborie, 'De l'opinion publique à l'imaginaire social', 104.

${ }^{69}$ For an overview, see S. Moscovici, 'The Phenomenon of Social Representations', in R. M. Farr and S. Moscovici (eds), Social Representations (Cambridge: Cambridge University Press, 1984), 1-69. It is worth noting, as Irwin Deutscher has, that Durkheim actually referred to 'social representations', and that it is only in English translation that the term 'collective representations was attributed to him (Deutscher, 'Choosing Ancestors: Some Consequences of the Selection from Intellectual Traditions', in Farr and Moscovici (eds), Social Representations, 74).
} 
the field of social psychology. Certainly, Denise Jodelet's definition of 'social representations' provides some much-needed clarity:

[social representations are] images that condense manifold meanings that allow people to interpret what is happening; categories which serve to classify circumstances, phenomena and individuals with whom we deal, theories which permit us to establish facts about them. When we consider social representations embedded in the concrete reality of our social life, they are all of the above together.70

Social representations thus enable us to understand how individuals - and in particular the decision-making elites - perceive the intangible notion of public opinion. In essence, public opinion (and the dominant tendencies of public opinion that subsequently inform policy choices) only assumes a concrete form inasmuch as 'social representations' make the imperceptible perceptible.

Social representations are thus the mechanism by which individuals make sense of a phenomenon that otherwise defies comprehension. In the words of Moscovici, 'we create representations in order to make familiar what is strange, disturbing, [and] uncanny.' Moreover, he suggests that 'social representations combine a semantic knowledge and a belief that is rooted in the culture together with the practices that people live by. This is what gives them a character of reality. ${ }^{71}$ Such a theoretical perspective is useful in explaining how political elites make sense of something as complex, intangible and fluctuating as public opinion. 'The theory of social representations ... takes as its point of departure the diversity of individuals, attitudes and phenomena, in all their strangeness and unpredictability', noted Moscovici: 'Its aim is to discover how individuals and groups can construct a stable, predictable world out of such diversity. ${ }^{72}$ In essence, therefore, we construct meaning through representation. As Stuart Hall has argued, 'representation' is the 'link between concepts and language which enables us to refer to either the "real" world of objects, people or events, or indeed to imaginary worlds of fictional objects, people and events.' It is thus through such mental representations - the

${ }^{70}$ Cited in C. Howarth, 'A Social Representation is Not a Quiet Thing: Exploring the Critical Potential of Social Representations Theory', British Journal of Social Psychology, xlv (2006), 67.

${ }^{71}$ S. Moscovici, 'Why a Theory of Social Representations?' in K. Deaux and G. Philogène (eds), Representations of the Social: Bridging Theoretical Traditions (Oxford: Blackwell, 2001), 20 \& 24.

${ }^{72}$ Moscovici, 'The Phenomenon of Social Representations', 44. 
imaginaire sociale - that events become defined and understood: 'Without them, we could not interpret the world meaningfully at all.'73

Hall goes on to define three broad theories of representation: the reflective approach, in which language as a representation acts as a mirror, reflecting a true meaning that already exists; the intentional approach, which contends that it is the actor who imposes his own meaning on the world through language; and finally, a constructivist approach, which holds that 'things don't mean: we construct meaning, using representational systems - concepts and signs.' Of the constructivist approach, Hall observes that social actors 'use the conceptual systems of their culture and the linguistic and other representational systems to construct meaning, to make the world meaningful and to communicate about that world meaningfully to others.' 74 It is a constructivist approach that lends itself to an analysis of public opinion via a conceptual notion of representations; public opinion only becomes 'meaningful' by virtue of how it is 'represented' and 'perceived'. In essence, one arrives at what John Durham Peters has termed the 'imagined public' which, crucially, is not imaginary at all: once these representations are perceived and acted upon, 'the public can come to exist as a real actor.' 75 The task for the historian is to locate, recreate, and analyse these representations.

In order to do so, this article posits that two distinct categories of representation be used: 'residual' representations and 'reactive' representations. Residual representations of public opinion are those that decision-makers refer to instinctively and intuitively; the accepted tendencies of opinion that are taken as a 'given', without any need for verification. When Holsti notes that 'decision-makers quietly anticipate public opinion without consciously doing so', he refers to anticipations constructed via residual representations that are established firmly within their cognitive maps. ${ }^{76}$ Although such representations need not be an accurate reflection of opinion (which might have subsequently evolved), they can retain an unrepresentative dominance and influence, potentially distorting the perceptions of public opinion held by policymakers. Indeed, Moscovici notes that representations 'are historical in their essence', emanating from people's experiences of the past. 77 All members of a society (including policymakers) are exposed to its dominant narratives and share many of the experiences that shape a national consciousness.

\footnotetext{
73 S. Hall, 'The Work of Representation', in Hall (ed.), Representation: Cultural Representations and Signifying Practices (London: Thousand Oaks, 1997), 17 (original emphasis).

74 Ibid. 25 (original emphasis).

75 J. D. Peters, 'Historical Tensions in the Concept of Public Opinion', in Glasser and Salmon (eds), Public

Opinion and the Communication of Consent, 16.

${ }^{76}$ Holsti, 'Public Opinion and Foreign Policy', 444.

77 Moscovici, 'The Phenomenon of Social Representations', 68.
} 
Such representations, and the perceptions of the national mood that they engender, also play a pivotal role in forging national identities, traditions, and memories, a constitutive element in the construction of an 'imagined community'. ${ }^{78}$ Crucially, these representations can assume any narrative form and are not always written down. Bradd Shore, for example, discusses at length the manner in which the Australian aboriginal 'Dreamworld' conveys and perpetuates specific rites and myths that shape the practices within a social group.79 Moreover, the potency of this 'imagined community', and the dominant assumptions, beliefs and 'legitimizing myths' that seemingly underpin it, necessarily contributes to policymakers' mental or cognitive 'maps', unconsciously informing the decision-making process. ${ }^{80}$ They can just as easily be unspoken, unwritten, even 'second nature', constituting part of what Pierre Bourdieu characterises as 'the habitus. ${ }^{81}$ Such 'residual' representations bear a striking resemblance to what Lippmann termed 'stereotypes' and 'preconceptions' and, what Allport, in 1937, labelled the 'older content' of opinion that provides the background against which perceptions of current public opinion are framed. ${ }^{82}$ Residual representations of public opinion are thus embedded and reassuring, providing us with structure where no genuine structure exists. In a sense, we already know what public opinion is. They offer, as Lippmann observed, 'a picture of a possible world to which we are adapted. [...] We feel at home there. We fit in. We are members. We know the way around.' ${ }_{3}^{3}$ Such residual representations are crucial in understanding how public opinion is perceived at any given time, and in any

\footnotetext{
78 This, of course, borrows from Benedict Anderson's Imagined Communities: Reflections on the Origin and Spread of Nationalism, revised edition (London: Verso, 1991).

79 B. Shore, Culture in Mind: Cognition, Culture, and the Problem of Meaning (Oxford: Oxford University Press, 1996), chapters 9 and 10. For a very useful overview of recent trends and developments in social representations research, see J. H. Liu and J. László, 'A Narrative Theory of History and Identity: Social Identity, Social Representations, Society, and the Individual', in G. Moloney and I. Walker (eds), Social Representations and Identity: Content, Process, and Power, (Basingstoke: Palgrave Macmillan, 2007), 85-107.

${ }^{80}$ For a discussion of the role of representations in constructing 'legitmizing myths', see J. Sidianus and F. Pratto, Social Dominance: An Intergroup Theory of Social Hierarchy and Oppression (Cambridge: Cambridge University Press, 1999), 45-9. For more on the notion of mental or cognitive 'maps', see A. K. Henrikson, 'The Geographical "Mental Maps” of American Foreign Policy Makers', International Political Science Review, i (1980), 495-530, Z. Steiner, 'Elitism and Foreign Policy: The Foreign Office Before the Great War', in B. J. C. McKercher and D. J. Moss (eds), Shadow and Substance in British Foreign Policy, 1895-1939 (Edmonton: University of Alberta Press, 1984), 19-56, and S. Casey and J. Wright (eds.), Mental Maps in the Era of Two World Wars (Basingstoke: Palgrave Macmillan, 2008).

${ }^{81}$ For more on Bourdieu's conception of 'habitus', and how it can be applied to the practice of international history, see Jackson, 'Pierre Bourdieu'.

82 W. Lippmann, Public Opinion, (London: George Allen \& Unwin, 1922), pp.89-90; Allport, 'Toward a Science of Public Opinion', 16-17.

83 Lippmann, Public Opinion, 95.
} 
historical context. Indeed, Yvon Lacaze echoed much of Lippmann's argument when writing of the mentalités collectives that 'juxtapose emotional and rational elements, such as ancestral preconceptions, myths and national stereotypes.' 84

In addition, such narratives can be formally or informally propagated in the classroom, inculcating a nation's youth with certain beliefs and convictions. For example, James Wertsch observed how Moscow schoolchildren in the late-1990s uniformly asserted that the western allies had intentionally delayed the opening of a second front in World War Two to the detriment of Russia. 85 Clearly, the old Soviet narrative lingered even beyond the end of the Cold War. Dominant narratives need not, however, be state-sanctioned. For example, the perception that interwar French society was profoundly pacifist was widespread, and it too was propagated in the classroom. ${ }^{86}$ Moreover, this particular narrative provided a potent residual representation of French opinion that not only informed many contemporary French decision-makers but was often shared by them, their pacifism borne out of the bitter memories of the Great War. This perception of a pacifist-infused society was difficult to shake, and almost certainly influenced French foreign and defence policy throughout this period. ${ }^{87}$ In a sense, this 'residual' representation of French pacifism became analogous to Caroline Howarth's description of 'hegemonic' social representations, which 'pervade the dominant social construction of reality.' Of course, if public opinion evolves, or even alters fundamentally, such representations cannot retain their hegemony indefinitely. As Howarth notes, they are contested by 'oppositional representations.' 88 In the methodological approach being suggested here, these can be labelled 'reactive representations' (as they need not be 'oppositional').

'Reactive' representations are the way in which public opinion is represented in the 'here and now', reflecting the ebbs and flows of opinion on any given issue and at any given time. The sources of such representations will naturally vary depending on the context, but can include opinion polls, newspaper commentary, television, radio or

\footnotetext{
84 Lacaze, L'opinion publique française et la crise de Munich, 47.

85 J. V. Wertsch, Voices of Collective Remembering (Cambridge: Cambridge University Press, 2002), 4-5.

${ }^{86}$ M. Siegel, “To the Unknown Mother of the Unknown Soldier”: Pacifism, Feminism, and the Politics of Sexual Difference among French Institutrices between the Wars', French Historical Studies, xxii (1999), 421-51. See also, by the same author, The Moral Disarmament of France: Education, Patriotism and Pacifism, 1914-1940 (Cambridge: Cambridge University Press, 2004).

${ }^{87}$ For example, Georges Bonnet has been characterized by his biographer as being part of 'la génération de feu', his aversion to war continuing to shape his policies as France's foreign minister in the late-1930s. See J. Puyaubert, Georges Bonnet: Les combats d'un pacifiste (Rennes: Presses Universitaires de Rennes, 2007), 150. For a more general overview of this subject, see D. Hucker, 'French Public Attitudes towards the Prospect of War in 1938-1939: “Pacifism” or “War Anxiety”?' French History, xxi (2007), 431-49.

${ }^{88}$ Howarth, 'A Social Representation is Not a Quiet Thing', 79.
} 
internet content, contemporary police reports, official and personal correspondence and conversation, even idle gossip and rumour. In essence, 'reactive' representations echo what Allport labelled the 'more recent content' of opinion, reflecting its evolution in response to 'a new stimulus' (namely contemporary events). ${ }^{89}$ The historian must identify which 'reactive' representations permeated the consciousness of the decision-makers and thus shaped their perception of opinion. Although such an approach can be criticised for examining 'elite' rather than 'mass' opinion, it is vindicated when the stated aim is to recreate the 'perceptions' of opinion held in policymaking circles. The accuracy of these perceptions is less important than their ability to inform policy decisions.

The historian must also, therefore, analyse the interplay between 'reactive' and 'residual' representations. To trace how perceptions of public opinion altered over time, it is necessary to examine the ability of 'hegemonic' residual representations to withstand the challenge of reactive representations (especially when the latter were 'oppositional'). Here it is worth noting Elisabeth Noelle-Neumann's influential 'spiral of silence' theory, which suggested that the public are unlikely to express any opinion that they perceive to be contrary to the prevailing sentiment.90 Therefore, 'reactive' representations may often reinforce the predominant 'residuals' simply because the latter are so potent that nobody is prepared to risk social exclusion by challenging them publicly. Moreover, it is also possible that decision-makers would fall victim to the 'looking-glass' perception, in which 'people appear to look out into the world and somehow see their own opinions reflected back.'91 Arguably, if a decision-makers' own opinion dovetailed with dominant residual representations of wider public opinion, it would be difficult to shake oneself from this conviction. Finally, one must consider the extent to which opinion could be 'led' by the government, manipulated or coerced into supporting a particular policy. For JeanJacques Becker, the ‘triumphant era of public opinion' ushered in by Rousseau's notion of 'popular sovereignty' had, by the turn of the twentieth century, given way to an 'triumphant era of manipulation', with governments coercing the masses through control of the media. ${ }^{2}$

\footnotetext{
89 Allport, 'Toward a Science of Public Opinion', 16-17.

90 E. Noelle-Neumann, The Spiral of Silence: Public Opinion - Our Social Skin (Chicago: University of Chicago Press, 1984).

${ }^{91}$ J. M. Fields and H. Schuman, 'Public Beliefs About the Beliefs of the Public', Public Opinion Quarterly, xl (1976), 437.

92 Becker, 'L'opinion publique: un populisme?', 92-6. For more on the various other 'theories' pertaining to perceptions of public opinion, see W. P. Eveland and C. J. Glynn, 'Theories on the Perception of Social Reality', in Donsbach and Traugott (eds), The SAGE Handbook of Public Opinion Research, 155-63, and C. J. Glynn, R. E. Ostman and D. G. MacDonald, 'Opinions, Perception, and Social Reality', in Glasser and Salmon (eds), Public Opinion and the Communication of Consent, 249-77.
} 
This latter concern, although of crucial importance when seeking to establish what public opinion actually was, is less troublesome when the focus is on elite perceptions of opinion. After all, decision-makers' attempts to manipulate opinion can reveal much about their perceptions of it in the first place. Furthermore, 'residual' representations provide the historian with a methodological tool for identifying some of the 'unspoken assumptions' that shaped an individual's 'mental map'. And, as James Joll has told us, 'one of the limitations of the documentary evidence is that few people bother to write down, especially in moments of crisis, things they take for granted.'93 Similarly, Pierre Renouvin noted more than forty years ago that certain influential opinions 'did not leave a paper trail' meaning that, 'in the analysis of opinion, there is always something that remains elusive.'94 However, evidence need not be as elusive as Renouvin believed, and international historians must not shy away from trawling the archival record for appropriate evidence. Other, more diverse sources (including newspapers, popular literature, cinema, diaries, even traces of gossip and rumour, etc.), can be used to recreate the wider social and cultural environment in which perceptions of public opinion were constructed. A more sophisticated understanding and awareness of these perceptions allows the historian to speculate more confidently about the actual influence wielded by public opinion. Moreover, this approach need not be confined to the influence of public opinion in a single country. How policymakers in one country perceived public opinion in another is also revealed through a study of representations, demonstrating how one country's public opinion could inform the foreign policy of another. 95

However, even utilising a plurality of sources cannot prevent our understanding of public opinion from being imperfect. There will always be gaps and absences, certain constituencies of opinion that are marginalised and silenced. Similarly, the fragmentary nature of any documentary record, coupled with the fact that certain perceptions of public opinion were frequently unspoken, means that the empirical paper trail will almost always be incomplete, leaving the historian little alternative but to make educated assumptions and forward cautious speculation. But none of this should be a deterrent.

\footnotetext{
93 J. Joll, 1914: The Unspoken Assumptions (London: Weidenfeld and Nicolson, 1968), 6.

94 P. Renouvin, 'L'opinion publique et la guerre en 1917', Revue d'histoire moderne et contemporaine, xv (1976),

4. Renouvin identified four types of sources available for the historian of public opinion: (1) the press; (2) material related to political parties, pressure groups, and trade unions; (3) official sources monitoring opinion, such as police reports; and (4) private correspondence of decision-makers, and their diaries and memoirs.

Renouvin acknowledged that all these sources are patchy and often unreliable, hence the 'elusive' nature of public opinion.

95 For examples, see W. Mulligan, 'The Alabama Affair and British Diplomacy, 1865-1872', in Mösslang and Riotte (eds), The Diplomats' World, 105-32, and Hucker, Public Opinion and the End of Appeasement, 22.
} 
Ultimately, there is too great an imbalance between the amount of existing scholarship in the field of international history that alludes to public opinion and the amount of scholarship devoted to analysing it. Consequently, international historians must overcome their reluctance to grasp the nettle of public opinion research, a reluctance that is, to a considerable extent, based upon a belief that opinion polls are the only accurate means of gauging what opinion was. Polls are seen as objective and scientific, furnishing reliable and indisputable data. But the fact remains that much international historical research concerns periods or countries where opinion poll data was not (or never has been) available. Consequently, historians of public opinion should heed the advice of James Beniger and Jodi Gusek who argued in the mid-1990s that the 'paradigm shift' of the cultural turn would result in 'public opinion and communication research' returning increasingly to 'the interdisciplinary arena.' 96

This article has, therefore, tried to present one possible (though by no means definitive) methodological strategy for exploring the role of public opinion, drawing inspiration from the disciplines of history, political science and social psychology. However, whilst embracing the interdisciplinarity encouraged by more recent trends in 'international' history, this approach exhibits a slight 'diplomatic twitch' and thus advocates a 'top-down' technique that is more akin to traditional 'diplomatic' history. The focus is (unapologetically) on the decision-making elites, whilst simultaneously embracing the approach advocated by Mösslang and Riotte, in which 'social, political, and cultural research can combine their findings to produce a rich, coherent, and fuller picture of international diplomacy.'97 Using a conceptual tool of 'representations', it is possible to isolate policymakers' ‘deeply ingrained' or ‘unspoken' assumptions about public opinion (residual representations) and examine how they interacted with the unstable 'reactive' representations as articulated through sources including newspapers, private and personal correspondence, parliamentary debates, police reports, and so on. Through such an endeavour, one can discern and re-create how policymakers perceived public opinion at any given time and in relation to any given event.

In essence, this methodology provides us with a means of 'catching our hare' - in this instance not public opinion as it was, but public opinion as it was perceived in decision-making circles, and thus a genuine actor in the foreign policymaking process. It suggests that locating and differentiating between two distinct categories of representation enables international historians to arrive at a more rigorous

\footnotetext{
${ }^{6}$ J. R. Beniger and J. A. Gusek, 'The Cognitive Revolution in Public Opinion and Communication Research', in Glasser and Salmon (eds), Public Opinion and the Communication of Consent, 236.

97 Mösslang and Riotte, 'Introduction: The Diplomats' World', 20.
} 
understanding of how something as intangible as public opinion came to have a tangible impact on foreign policy decisions. For too long, the role of public opinion has been overlooked, or merely alluded to in passing. As a result, its influence has been simply ignored or misunderstood, vulnerable to lazy assumption and supposition. The conceptual framework forwarded here is intended to rectify this failing. An approach focused on representations, differentiating between the 'reactive' representations traceable via the documentary record and 'residual' representations that rely on a more creative recreation of the social universe in which policymakers were acting, affords a more nuanced and sophisticated reading of public opinion's influence than historians have provided hitherto. It may not convince everyone, and it is certainly imperfect, but it is hoped that it is, at the very least, a step in the right direction. 